\title{
Investigation of Structure and Composition of Clay in Lakes of Latgale for Practical Use
}

\author{
Rasma Tretjakova \\ Faculty of Engineering \\ Rezekne Academy of Technologies \\ Rezekne, Latvia \\ rasma.tretjakova@rta.lv
}

\author{
Gotfrīds Noviks \\ Faculty of Engineering \\ Rezekne Academy of Technologies \\ Rezekne, Latvia \\ gotfrids.noviks@rta.lv
}

\author{
Gundars Mezinskis \\ Faculty of Materials Science and \\ Applied Chemistry \\ Riga Technical University Institute \\ of Silicate Materials \\ Riga, Latvia \\ Gundars.Mezinskis@rtu.lv
}

\begin{abstract}
Sedimentary clay of three Latvia region of Latgale lakes - Zeili, Pauguḷi and Plusons - was investigated. Mineral composition was determined by $X$-ray diffraction, the average size and size distribution of particles by dynamic light scattering method, specific surface by Brunauer-Emmett-Teller method, and adsorption characteristics after methylene blue: adsorption capacity and adsorption isotherms. The samples contained typical clay crystalline phases - illite, kaolinite - and rock forming minerals - quartz, dolomite, calcite, plagioclase, albite, and enstatite. The granulometric content of samples is mostly characterised by silt $(2-63 \mu \mathrm{m})$ and clay $(<2 \mu \mathrm{m})$ fractions. Specific surface area varied from 9.45 to $20.68 \mathrm{~m}^{2} / \mathrm{g}$. The adsorption capacity of lake clay was in the range of 25.8 - $45.8 \mathrm{mg} / \mathrm{g}$. Clay adsorption isotherms were represented by the second and fifth type curves according to the International Union of Pure and Applied Chemistry (IUPAC) classification, indicating the presence of micro- and macroporous space in samples and strong intermolecular interactions. The difference between properties of clay in different lakes and at different depths and their influencing factors have been clarified. The information obtained enables to predict the areas of use of clay in cosmetics and medical treatment.
\end{abstract}

Keywords - lake clay, mineral composition, granulometric content, adsorption capacity.

\section{INTRODUCTION}

Clay is one of the most frequently found and accessible mineral deposits. Latvia is one of the European countries that is richest in clay, calculating per resident [1]. However, the potential of local clay is not being used sufficiently; for example, the prevailing amount $(40.8 \%)$ of cosmetic products containing clay that can be purchased in Latvia is produced in France and only $3.2 \%$ is produced in Latvia [2].

Latvia is rich in waters; its territory contains 2256 lakes with the water surface area over 1 ha and the total area about $1001 \mathrm{~km}^{2}$, which is $1.5 \%$ of the territory of Latvia [3]. The natural resources of the lakes - the sapropel - have been studied extensively, and under the sapropel layer, layers of clay deposits have also been found. There are about 1000 lakes in Latgale with the properties of their clay deposits unstudied. Having analysed the reports of SIA "Geo Consultants" on the search of lake sapropel deposits in 199 lakes studied in the former Preili, Ludza and Rēzekne regions, lake clay has been found in the soil of 109 lakes. The study and scientific substantiation of the opportunities for the use of lake clay as a local resource will create a foundation and a favourable environment for the design of new products and services.

All types of clay minerals have been reported in soils. Recent sediments include lake clay as well. Smectite, illite, kaolinite and chlorite are major components found both in nonmarine and marine sediments [4].

The use of clays (probably smectite) as soaps and absorbents was reported in Natural History by the Roman author Pliny the Elder (c. 77 ce) [4]. Nowadays clay has a wide range of application. The effectiveness of the use of clay in cosmetology and dermatology has been proven [5] - [11]. French clay, which is obtained in pits from the deepest layers of the lithosphere, has been studied extensively. The opportunities for the use of French green clay in cosmetology and dermatology have also been proven [8], [12]. Clay hydrates the skin and makes it smooth, restores its elasticity, normalises the activity of sebaceous glands, cleans, nourishes, disinfects, treats the skin [11], [13] - [17]. Latvian illite clay can be used as one of UV filters in sun protection creams, in addition giving the cream a light brown tint. A prototype cream with SPF about 9 has been created [18].

Clay is used in cosmetics for its large specific surface, granulometric content, sorption, adhesion, neutral $\mathrm{pH}$, high thermal capacity, tissue astringent properties [19] - [22]. The sorption properties of clay are used in the treatment of different dermatological diseases such as acne, rash, ulcers and seborrhea [23].

There are many studies on clay found in the overland lithospheric layers; lake clay is understudied globally; whereas in Latvia there are no such studies at all. Transformation of lake clay located under the layer of sapropel has occurred under the influence of organic

Print ISSN 1691-5402

Online ISSN 2256-070X

https://dx.doi.org/10.17770/etr2019vol1.4069 (C) 2019 Rasma Tretjakova, Gotfrīds Noviks, Gundars Mezinskis. Published by Rezekne Academy of Technologies. This is an open access article under the Creative Commons Attribution 4.0 International License. 
substances, and due to the different biochemical processes its properties may be different from lithospheric clay.

The most important parameters that determine the properties of clay and thus also its application opportunities are the mineral and granulometric content of clay [24], thus the aim of this study is to determine the mineral content, granulometric content, specific free surface, adsorption level and adsorption isotherms of lake clay.

\section{MATERIALS AND METHODS}

Sediment samples were taken in winter from the ice of lake Zeiḷi, Pauguli, and Plusons (Latvia). In lake Zeili the samples were taken from 2 control boreholes $-Z 2$ and $Z 4$. In control borehole $Z 2$ the samples were taken from 4 depths measuring from the water surface $-Z 2.6$ (6 m depth), Z2.7 (7 m depth), Z2.8 (8 m depth), Z2.9 (9 $\mathrm{m}$ depth), in control borehole $Z 4$ - from 1 depth $Z 4.8$ (8 $\mathrm{m}$ depth). In lake Pauguli the samples were taken from 1 control borehole at the depth of $3.5 \mathrm{~m}$, in lake Plusons - from 1 control borehole at the depth of $8 \mathrm{~m}$. The equipment used to obtain clay was designed analogous to a sampler (the "Eijkelkamp" type) with 2 1 camera. Samples are placed into sterile plastic packaging.

A qualitative analysis of the crystalline phases of mineral content was performed using Rigaku's Ultima $+X$-ray diffraction system [25]. Copper cathode radiation was used, scan speed $1 \%$ min, voltage $40 \mathrm{kV}$, current intensity $5 \mathrm{~mA}, 2 \theta$ scan angle range $5-60^{\circ}$. Data processing software - Jade MDI9. Electronic ICDD databases - PDF-4Organics/Organics 2017 were used for results interpretation and crystal identification.

To determine the granulometric content, dynamic laser diffraction analysis with Broohaven Instruments device with $B I-A P D$ photodiode detector was used. The device can determine particles of radius from 1.5 to $3 \mu \mathrm{m}$. The method is based on the relation between particle diffusion rate D undergoing Brownian Motion and their size $d$, expressed by the StokesEinstein equation

$$
d=k T / 3 \pi \eta D
$$

where $k$ - Boltzmann's constant, $T$ - temperature, $\eta$ - viscosity.

For the measurement of the sizes of the samples and their distribution, $0.5 \%$ clay mass and water suspensions were created. To stabilise the system, the surface active ingredient poly-I-lysine was added. The solution was first stirred for one hour and subjected to a 10-minute ultrasonic treatment. The measurements were performed at the temperature of $25^{\circ} \mathrm{C}$ with laser radiation power $15 \mathrm{~mW}$ and wavelength $658 \mathrm{~nm}$, and scan angle $90^{\circ}$.

To calculate the specific free surface area $S_{t}$, the BET (Brunauer, Emmett and Teller) method was used. The specific surface $S_{t}$ of granulated material is determined by physically absorbing gas on solid particle surfaces and calculating the amount of adsorbate gas $W_{m}$, which corresponds to the monomolecular layer on the surface [26]. Nitrogen was used as the adsorbate.

$$
S_{t}=W_{m} \cdot N \cdot A_{c s} / M
$$

where $N$ - the Avogadro number $\left(6.022 \times 10^{23}\right.$ $\left.\mathrm{mol}^{-1}\right), M$ - the molecular mass of the adsorbate (nitrogen), $A_{c s}$ - the cross-section area of the adsorbate molecule (for nitrogen at $T=77 \mathrm{~K} A_{c s}=16.2 \times 10^{-18} \mathrm{~m}^{2}$ ), $W_{m}$ - the monolayer mass of the adsorbate (nitrogen) at relative pressure $P / P_{0}$.

To determine the adsorption capacity of clay, the methylene blue test was used [27], [28]. The dependence between the optical density of the methylene blue solution and the methylene blue concentration in ranges $20-100 \mathrm{mg} / \mathrm{l}$ and $100-700$ $\mathrm{mg} / \mathrm{l}$ was determined experimentally with the spectrophotometer, light wavelength $400 \mathrm{~nm}$. Calibration charts were constructed on the basis of the experimental data.

To measure the adsorption level of clay, the standard methylene blue solution (MB) with the concentration of $1 \mathrm{~g} / \mathrm{l}$ was prepared. Clay samples were dried and granulated. For measurement, $1 \mathrm{~g}$ of the corresponding clay was poured into a flask, $50 \mathrm{ml}$ of standard MB solution were added and subjected to stirring for 30 minutes. Then the suspension was centrifuged, and samples were taken to determine the optical density in cuvettes in $1 \mathrm{~cm}$ layer of the analysed solution.

Using the calibration curves of the corresponding range, the $\mathrm{MB}$ concentration was determined in these solutions subjected to adsorption. The adsorption level of clay $A_{d}$ was calculated using the formula

$$
A_{d}=\left(C_{0}-C_{1}\right) \cdot \frac{V}{m}, \mathrm{mg} / \mathrm{g}
$$

where $C_{0}$ - initial MB concentration $(1000 \mathrm{mg} / \mathrm{l})$, $C_{1}$ - MB concentration after adsorption, mg/l, $V$ volume of the solution $(50 \mathrm{ml}), m$ - mass of the clay sample (1 g).

Each measurement was repeated three times - in all cases the difference between measurements did not exceed $0.5-0.7 \%$. Considering the natural nonhomogeneity of clay, the precision of these data is fully satisfactory. For further calculations, the average numbers from these measurements were used. To determine the effect of the stirring time of the suspension on the adsorption level, parallel experiments were performed with 5-hour sample stirring time, which showed that the adsorption level increases but very insignificantly - by $5 \%$ only (e.g., $44.5 \mathrm{mg} / \mathrm{g}$ to $46.8 \mathrm{mg} / \mathrm{g}$ ). This means that the 30 -minute sample stirring time is sufficient for the assessment of the adsorption capacity of clay. 
Adsorption isotherms were also determined using methylene blue. Initial adsorbate - MB concentrations were selected as follows: $0.05,0.1,0.5,0.7 \mathrm{~g} / \mathrm{l}$. For comparison, according to an analogous method, the adsorption isotherm was also determined for two clay samples from Kuprava clay deposit.

\section{RESULTS AND DISCUSSION}

The experimental data obtained are summarised in Table I.

According to granulometric content, sediments are divided into two groups - lake Zeili clay (Z2.8) from the depth of $8 \mathrm{~m}$ and lake Plusons sediments are characterised by the monomodal particle distribution curve according to size with rather narrow scattering of sizes (Figure 1) but very different effective diameter of the particles; the size of the particles of lake Plusons sediments is almost 4 times greater than the size of the particles of lake Zeili sediments (Table 1).

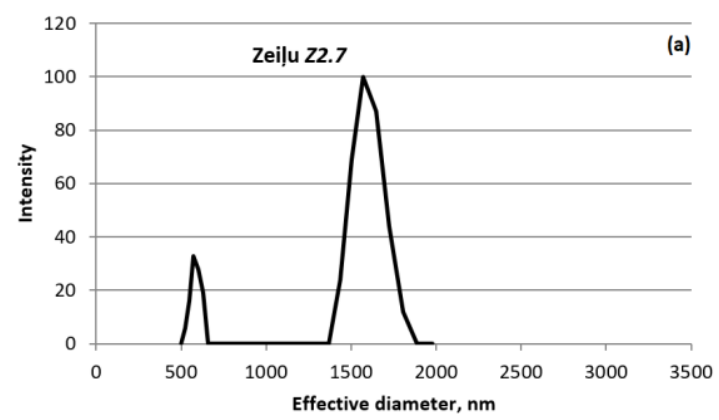

The comparison of the other sample particle sizes has a drastically pronounced bimodal character with the effective diameter of the particles within the limits of 568.3 - $948.6 \mathrm{~nm}$ (Figure 2 and 3).

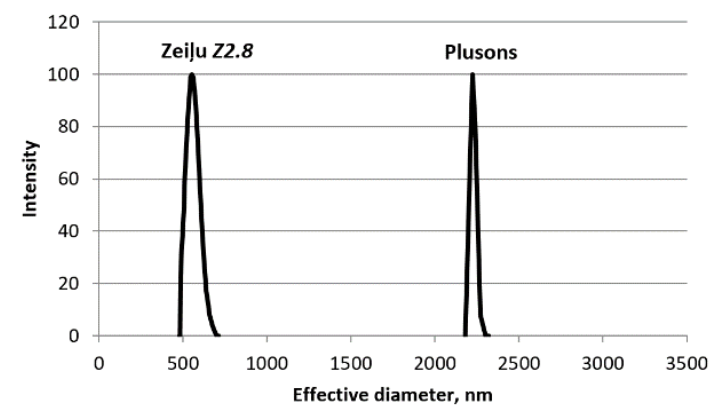

Fig. 1. Comparison of the monomodal granulometric conten curves of lake Zeili sample Z2.8 and lake Plusons sediments

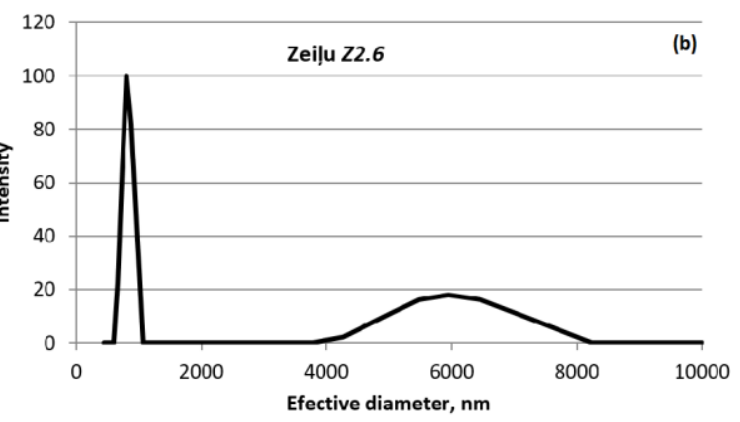

Fig. 2. Bimodal clay particle distribution in lake Zeiḷi samples $Z 2.7$ (a) and $Z 2.6$ (b)

TABLE I. LAKE SEDIMENT PROPERTIES

\begin{tabular}{|c|c|c|c|c|c|c|}
\hline \multirow[t]{2}{*}{ Samples } & \multicolumn{3}{|c|}{ Granulometric content, nm } & \multirow{2}{*}{$\begin{array}{c}\text { Specific } \\
\text { surface area, } \\
\mathrm{m}^{2} / \mathrm{g}\end{array}$} & \multirow{2}{*}{$\begin{array}{c}\text { Adsorption } \\
\text { level MB, } \\
\text { mg/g }\end{array}$} & \multirow{2}{*}{$\begin{array}{l}\text { Mineral } \\
\text { content }\end{array}$} \\
\hline & $\begin{array}{c}\text { Average diameter } \\
d_{v}\end{array}$ & $\begin{array}{c}\text { Effective diameter } \\
d_{\text {ef }}\end{array}$ & Typical ranges & & & \\
\hline Pauguḷi & 918.6 & 675.0 & $\begin{array}{c}498.9-716.6 \\
2122.7-3048.7\end{array}$ & 15.80 & 37.5 & $Q, I, D, C, P, K$ \\
\hline Plusons & 2228.3 & 2245.5 & $2194-2255$ & 9.45 & 41.5 & $Q, D, C, A, E$ \\
\hline Zeiḷi Z2.6 & 1853.2 & 993.7 & $\begin{array}{c}658.4-971.1 \\
4261.8-7024.2\end{array}$ & 20.21 & - & $Q, I, D, C, P, K$ \\
\hline Zeiḷi Z2.7 & 1358.0 & 998.6 & $\begin{array}{c}523.1-568.4 \\
1433.8-1803.1\end{array}$ & 20.32 & 45.8 & $Q, I, D, C, P, K$ \\
\hline Zeili Z2.8 & 558.3 & 568.3 & $485.4-683.7$ & 20.68 & 30.5 & $Q, I, D, C, P, K$ \\
\hline Zeiḷi Z4.8 & 991.3 & 800.7 & $\begin{array}{c}594.7-783.8 \\
1794-2364\end{array}$ & 17.41 & 41.0 & $Q, I, D, C, P, K$ \\
\hline Zeili Z2.9 & - & - & - & - & 25.8 & $Q, I, D, C, P, K$ \\
\hline Kuprava $K 1$ & - & - & - & - & 48.8 & $I, Q, O, C, K$ \\
\hline Kuprava $K 2$ & - & - & - & - & 48.4 & $I, Q, O, C, K$ \\
\hline
\end{tabular}

$Q$ - quartz, $I$ - illite, $D$ - dolomite, $C$ - calcite, $K$ - kaolinite, $O$ - orthoclase, $P$ - plagioclase, $A$ - albite, $E$ - enstatite

Specific free surface of all lake Zeili clay with the exception of sample $Z 4.8$ is almost equal to $20.20-20.68 \mathrm{~m}^{2} / \mathrm{g}$ (Table 1). For lake Pauguli and Z4.8 samples it is lower $\left(15.08-17.41 \mathrm{~m}^{2} / \mathrm{g}\right)$, but for lake Plusons sediments it is the lowest $\left(9.45 \mathrm{~m}^{2} / \mathrm{g}\right)$, which can be explained by the significantly higher coarseness level of these sediments.

Adsorption capacity measurements show that it does not correlate with the size of the sediment particles or the specific surface. Thus, one of the highest MB adsorption capacities $(41.5 \mathrm{mg} / \mathrm{g})$ was demonstrated by the coarsest sediments of lake Plusons. Lake Zeili samples Z2.7 and Z4.8 demonstrated the highest adsorption capacity $(45.8-41.0 \mathrm{mg} / \mathrm{g})$. The adsorption 300 capacities of the other samples is between 25.8 and 37.5 $\mathrm{mg} / \mathrm{g}$. The adsorption isotherms of the lake sediments studied can also be divided into two groups. Lake Pauguḷi and lake Zeili clay sample Z2.9 and Z2.8 isotherms correspond to type IV, but Z4.8, Z2.7 and lake Plusons sample isotherms correspond to type II according to IUPAC classification [29] (Figure 4).

The results of the study have shown that lake Pauguḷi and lake Zeili sediments have identical mineral composition, which includes two clay minerals - illite and kaolinite (Table 1) and non-clay fractions - quartz, dolomite, calcite, orthoclase, plagioclase, albite, enstatite. Mattioli et al. 2016 also note in their studies that commercial clays used in cosmetics none are pure 
clay and are characterized by the presence of a significant non-clay fraction dominated by calcite and

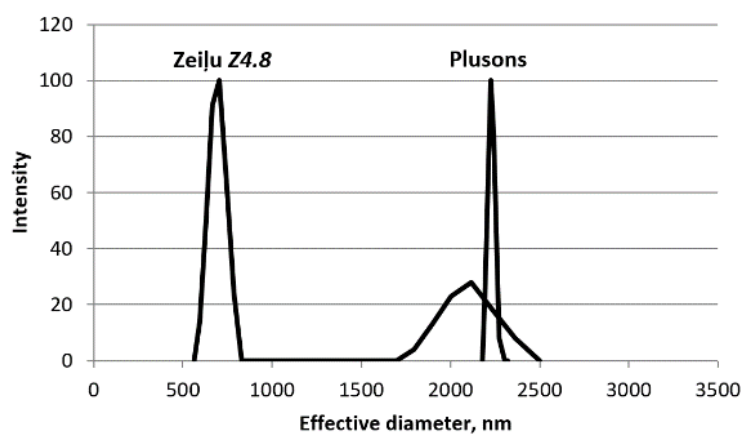

quartz, and to a minor extent by dolomite, feldspars and gypsum [30].

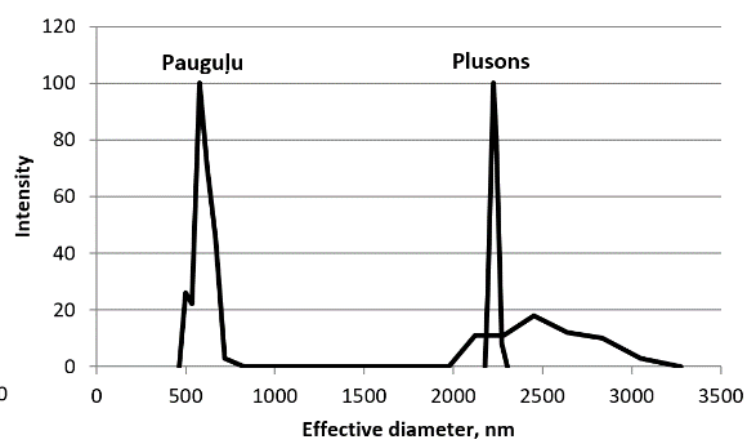

Fig. 3. Comparison of lake Zeịi and lake Pauguḷi sediment granulometric content with lake Plusons sediment monomodal distribution

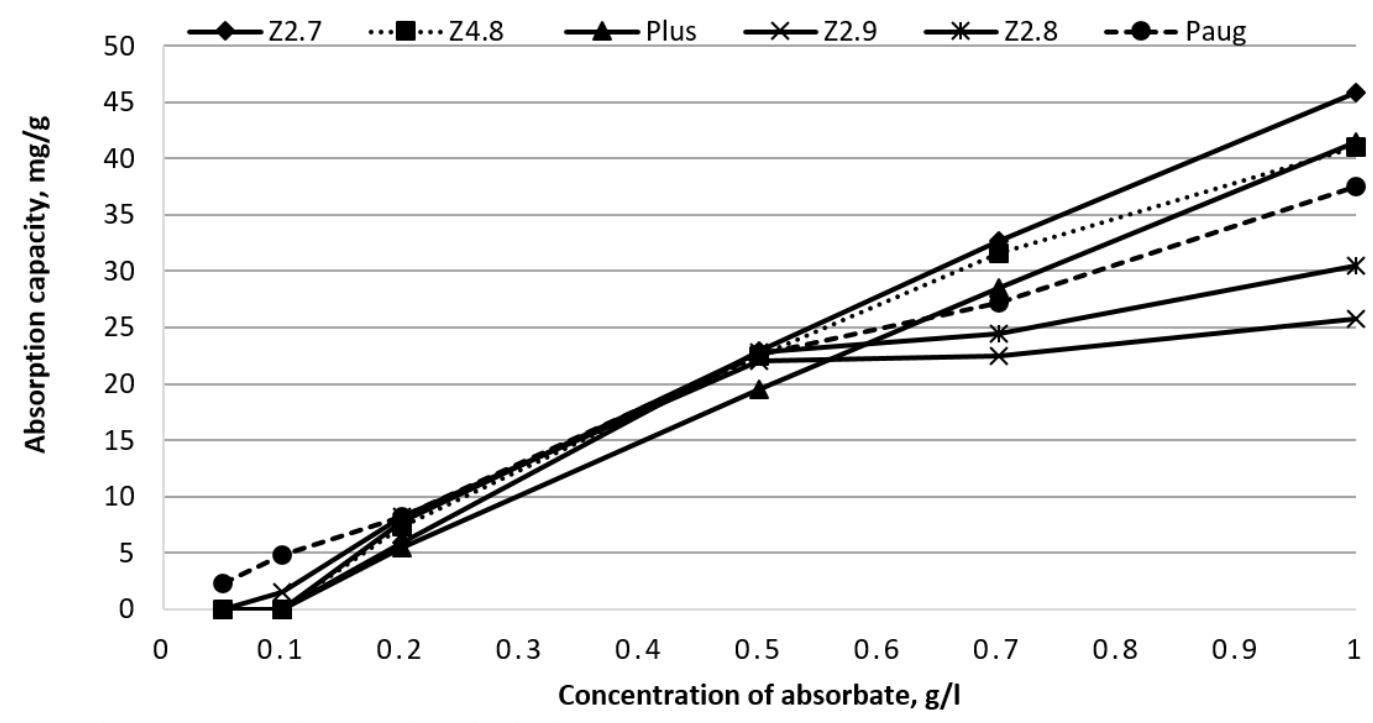

Fig. 4. Lake sediment type IV and type II adsorption isotherms

Lake Plusons sediments are different. Since these do not contain any clay minerals, they cannot be considered clay sediments. They are also characterised by other differences in properties - a significantly higher particle coarseness level - up to $0.23 \mu \mathrm{m}$, very high homogeneity of the particles according to size (homogeneity coefficient 0.99 , polydispersity 0.005 ), drastically smaller specific surface area in comparison to the sediments of other lakes $\left(9.45 \mathrm{~m}^{2} / \mathrm{g}\right)$. However, these sediments show an unexpectedly high adsorption level - $41.5 \mathrm{mg} / \mathrm{g}$ compared to other samples which have a significantly smaller effective diameter of particles and a larger specific surface (e.g., $A_{d}$ of sample $Z 2.8$ is $30.5 \mathrm{mg} / \mathrm{g}$, where $d_{e f}=568.3 \mathrm{~nm}$ and $S=20.68$ $\mathrm{m}^{2} / \mathrm{g}$ ). This means that the difference of the adsorption level is related to the chemical composition of these adsorbents. Since the crystalline phase content, determined using the diffractometric method, has qualitatively shown the identity of these samples (with the exception of lake Plusons sediments), the determining factor in difference of adsorption capacity becomes the physical and chemical nature of the interaction with the adsorbate, including the amount and content of organic matter in these sediments. The other clay samples are characterised by the nonhomogeneity of the size of different particles from 1.00 to 1.86 (Table II).
From the analysis of the data for all samples, a small tendency for the increase of the specific surface with the decrease of the particle size can be observed (regression coefficient $R^{2}=0.3$ ). From the analysis of the samples of particular groups (e.g., lake Zeili samples Z2.6, Z2.7, Z2.8), a much stronger correlation between the depth of the deposit and dispersity can be observed - with greater depth, a greater percentage of fine particles is found in the sediments $\left(R^{2}=0.96\right)$. The highest particle size scatter was demonstrated by top layers of lake Zeili sediments $-1.36-1.86$. Adsorption isotherms (Table 2) in lake Zeili clay taken from greater depth (8, 9 metres) are type four curves showing an increase of adsorption capacity directly proportional to the increase of adsorbate concentration up to $0.5 \mathrm{~g} / 1$, followed by the zone of saturation within the adsorbate concentration limits $0.5-0.7 \mathrm{~g} / \mathrm{l}$, then again followed by a directly proportional but less intensive increase of adsorption capacity (Figure 4). Zone of saturation means that in this range the formation of the adsorbed monomolecular layer on particle surfaces ends, at higher concentrations next adsorption layers begin to form. In accordance with the literature data, such isotherm nature is characteristic of mesoporous adsorbents with strong affinities between the adsorbent and the adsorbate [31]. 
The other sample (Z2.7, Z4.8, Plusons) isotherms can be attributed to type II curves, which do not have the intermediate saturation stage. These curve types indicate the macroporous structure of the adsorbent with a homogenous particle surface and strong affinity between the adsorbent and the adsorbate. It is noteworthy that the adsorption levels up to adsorbate concentration $0.5 \mathrm{~g} / \mathrm{l}$ almost coincide. The differences start at higher concentrations, and at the maximum adsorbate concentration $1 \mathrm{~g} / \mathrm{l}$ studied, it is lower for type IV clay (Figure 4). Adsorption isotherms from Kuprava clay deposit show no principal difference from lake sediment isotherms; these are attributed to type II isotherms and are also characterised by a higher adsorption level, and their adsorption level at adsorbate concentration $1 \mathrm{~g} / \mathrm{l}$ is higher than that of lake sediments and exceeds $49 \mathrm{mg} / \mathrm{g}$. Kuprava clay diffractogram shows that its composition is primarily formed by illite [32], which determines its increased adsorption capacity. Other studies [33] have found that clay adsorption level is $90-125 \mathrm{mg} / \mathrm{g}$. Whereas clay from

\begin{tabular}{|c|c|c|c|c|}
\hline Samples & $\begin{array}{c}\text { Granulometric content } \\
\text { curve type }\end{array}$ & $\begin{array}{c}\text { Particle } \\
\text { nonhomogeneity } \\
\text { coefficient, } \boldsymbol{d}_{v i d} / d_{e f}\end{array}$ & Polydispersity & Isotherm type \\
\hline Pauguḷi & Bimodal & 1.36 & 0.139 & Type IV \\
\hline Plusons & Monomodal & 1.00 & 0.005 & Type II \\
\hline Zeili Z2.6 & Bimodal & 1.86 & 0.209 & - \\
\hline Zeili Z2.7 & Bimodal & 1.36 & 0.137 & Type II \\
\hline Zeili Z2.8 & Monomodal & 1.00 & 0.005 & Type IV \\
\hline Zeili $Z 4.8$ & Bimodal & 1.16 & 0.129 & Type II \\
\hline Zeili Z2.9 & - & - & - & Type IV \\
\hline Kuprava $K 1, K 2$ & - & - & - & Type II \\
\hline
\end{tabular}

\section{CONCLUSIONS}

Lake clay contains typical clay crystalline phases illite, kaolinite, and rock forming minerals - quartz, dolomite, calcite, plagioclase, albite, and enstatite. The granulometric content of lake clay is mostly characterised by silt $(2-63 \mu \mathrm{m})$ and clay $(<2 \mu \mathrm{m})$ fractions. Specific surface area varies from 9.45 to $20.68 \mathrm{~m}^{2} / \mathrm{g}$. Adsorption capacity of lake clay varies from 25.8 to $45.8 \mathrm{mg} / \mathrm{g}$. Lake clay, considering its mineralogical and granulometric content, specific surface area and adsorption capacity, is suitable for use in cosmetics and medical treatment.

\section{REFERENCES}

[1] V. Segliňš, A. Brangulis, Resources of the Latvian Earth Entrails. Rīga: State Environmental Service, Technical University Press, 1996. [V. Segliņš, A. Brangulis, Latvijas zemes dz̄ị ru resursi. Rīga: Valsts vides dienests, Tehniskās universitātes tipogrāfija], 1996. (in Latvian).

[2] J. Vecstaudža, A.Stunda-Zujeva, Z. Irbe, L. Bērziṇa-Cimdiṇa, "Composition of Commercial Cosmetic Clay and Suitability of Latvian Clay for Cosmetic Purposes," ["Komerciālo kosmētisko mālu sastāvs un Latvijas mālu piemērotība lietojumam kosmētikā,'] Material Science and Applied Chemistry, vol. 26, pp. 42 -48., 2012. (in Latvian).

[3] M. Leinerte, Lakes are Burning! [Ezeri deg!] Rīga: Zinātne, 1988. (in Latvian).

[4] R. E. Grim, H. Kodama, Clay mineral.[Online]. Available: https://www.britannica.com/science/clay-mineral\#ref80125 [Accessed November 29, 2018].

[5] S. Haydel, C. Remenih, L. Williams, "Broad-spectrum in vitro antibacterial activities of clay minerals against antibiotic- other deposits shows a significantly lower adsorption level; Nīcgale clay deposit studies [34] have demonstrated the MB adsorption level of $14.3-19.8$ $\mathrm{mg} / \mathrm{g}$ with the specific surface of $23.8 \mathrm{~m}^{2} / \mathrm{g}$. The adsorption capacity of the lake sediments studied is not great in comparison, for example, with clay used in medicine, which contains montmorillonite, which has a specific area of $173 \mathrm{~m}^{2} / \mathrm{g}$ and a sorption capacity of 370 $\mathrm{mg} / \mathrm{g}[35,36]$.

Clays used in pharmaceutics and cosmetics should have a high specific surface area [30], [37]. However, in comparison with cosmetic clay used, the specific surface area of which does not exceed $2.4 \mathrm{~m}^{2} / \mathrm{g}$ [38], the specific surface area of lake clay is suitable for use for cosmetic and medical purposes. According to granulometric content, clay from the lakes of Latgale also corresponds to the therapeutic clay already used in treatment procedures [39]. The average particle size of commercial cosmetic clay varies from 2.4 to $12.0 \mu \mathrm{m}$ [2]. 
Environment. Technology. Resources. Rezekne, Latvia Proceedings of the 12th International Scientific and Practical Conference. Volume I, 298-303

[13] M.I. Carretero, C.S.F. Gomes, F. Tateo, "Clays and human health," In: F. Bergaya F, Theng BKG, Lagaly G, editors. Handbook of Clay Science. Elsevier Ltd, 2006. pp. 717-741.

[14] M.V.R. Velasco, V. Zague, M.F. Dario, D. O. Nishikawa, C.A.S.O. Pinto, M. M. Almeida, G. H. G.Trossini, A.C. V.Coelho, A. R. Baby. "Characterization and Short-Term clinical study of clay facial mask," Journal of Basic and Applied Pharmaceutical Science Rev Ciênc Farm Básica Apl, vol. 37, no.1, pp.1-6, 2016.

[15] L. Meier, R. Stange, A. Michalsen, B. Uehleke, "Clay jojoba oil facial mask for lesioned skin and mild acne - results of aprospective, observational pilot study," Forsch Komplementmed, vol.19, pp. 75-79, 2012.

[16] S.F. Mpuchane, G-IE. Ekosse, B.A. Gashe, I. Morobe, S.H Coetzee, "Microbiological characterisation of southern African medicinal and cosmetic clays," Environ Health Res., vol. 20, no.1, pp. 27-41, 2010.

[17] C. Viseras, C. Aguzzi, P. Cerezo, A. Lopez-Galindo, "Uses of clay minerals in semisolid health care and therapeutic products," Applied Clay Science, vol. 36(1-3), pp. 37-50, 2007.

[18] State research programme 2014.10-4/VPP-6/6 "A Study of Forest and Earth Entrail Resources, Sustainable Use - New Products and Technologies" (ResPod) (2014-2017). A Study of Earth Entrail Resources - New Products and Technologies (Land) [Valsts pētījumu programma 2014.10-4/VPP-6/6 "Meža un zemes dzịḷ resursu izpēte, ilgtspējīga izmantošana - jauni produkti un tehnologijas" (ResProd) (2014-2017). Zemes dzịlu resursu izpēte - jauni produkti un tehnologijas (Zeme)]. (in Latvian)

[19] A. López-Galindo, C. Viseras, P Cerezo, "Compositional, technical and safety specifications of clays to be used as pharmaceutical and cosmetic products," Applied Clay Science, vol. 36, no. 1-3, pp. 51-63, 2007.

[20] M. I. Carretero, M. Pozo, "Clay and non-clay minerals in the pharmaceutical and cosmetic industries Part II. Active ingredients," Applied Clay Science, vol. 47, no. 3-4, pp. 171181, 2010.

[21] M. Çelik Karakaya, N. Karakaya, Ş. Sarıoğlan, M. Koral, "Some properties of thermal muds of some spas in Turkey," Applied Clay Science, vol. 48, no. 3, pp. 531-537, 2012.

[22] J. Legido, C. Medina, M. L. Mourelle, M.I. Carretero, M. Pozo, "Comparative study of the cooling rates of bentonite, sepiolite and common clays for their use in pelotherapy," Applied Clay Science, vol. 36, no. 1-3, pp. 148-160, 2007.

[23] Bergaya, F., Theng, B. K., Lagaly, G. Handbook of Clay Science. Elsevier Science, 2006.

[24] A. Stinkule. Clay in the Entrails of the Latvian Land. Rīga: RTU Press. [Māli Latvijas zemes dzīlēs. Rīga: RTU izdevniecība], 2014.

[25] D. M. Moore, R. C. Reynolds, Jr., X-Ray Diffraction and the Identification and Analysis of Clay Minerals, Oxford University Press, New York, Ch. 1, 2, \& 3.1989.

[26] BET (Brunauer, Emmett and Teller) [Online]. Available: http://particle.dk/methods-analytical-laboratory/surface-areabet-2/ [Accessed January 2, 2019].

[27] A.U. Itodo , F.W .Abdulrahman, L.G. Hassan, S.A.Maigandi, H.U. Itodo, "Application of Methylene Blue and Iodine Adsorption in the Measurement of Specific Surface Area by four Acid and Salt Treated Activated Carbons," New York Science Journal, vol.3, no. 5, 2010.

[28] ASTM C837-09(2014), Standard Test Method for Methylene Blue Index of Clay, ASTM International, West Conshohocken, PA, 2014, [Online]. Available: www.astm.org. [Accessed December 12, 2018].

[29] M. Khalfaoui, S. Knani, M.A. Hachicha, A. BenLamine, "New theoretical expressions for the five adsorption type isotherms classified by BET based on statistical physics treatment", Journal of Colloid and Interface Science," vol. 263, Issue 2, pp. 350-356, 15 July 2003.

[30] M. Mattioli, L.Giardini, C. Roselli, D. Desideri, "Mineralogical characterization of commercial clays used in cosmetics and possible risk for health," Applied Clay Science, vol. 119, pp. 449-454, 2016.

[31] M. Donohue, "A New Classification of Adsorption Isotherms," [Online]. Available: http://www.nigelworks.com/mdd/PDFs/NewClass.pdf [Accessed: January 21, 2019].

[32] V. Puzule, G. Noviks, "The composition and usefulness perspectives of Katlesi geological suite of Mednieki deposit clay," International symposium "Clays and Ceramics" University of Latvia, 29-31 January, 2018.

[33] E.Ts. Dashinamzhilova, S.Ts. Hanhasayeva, L.V. Bryzgalova, A.A. Savina, "Physical and Chemical Properties of Natural Clays in Deposits of Buryatia", Success of Modern Natural Sciences, no. 6, pp. 13-17, 2017. [Э.Ц. Дашинамжилова, С.Ц. Ханхасаева, Л.В. Брызгалова, А.А. Савина “Физикохимические свойства природных глин месторождений Бурятии," Успехи современного естествознания № 6, pp. 13-17, 2017]. [Online]. Available: http://naturalsciences.ru/ru/article/view?id=36491 [Accessed January 29, 2019]. (in Russian).

[34] V.Lakevičs. Latvijas mālu sorbcijas īpašības [Latvian Clay Sorption Properties]. Rīga: RTU, 2006 (in Latvian).

[35] A.N. Tishin, U.A. Krut, O.M. Tishina, E.A. Beskhmelnitsyna, V.I. Yakushev, "Physico-chemical properties of montmorillonite clays and their application in clinical practice (review) Research result: pharmacology and clinical pharmacology," vol. 3, no. 2, pp. 119-128, 2017.

[36] G.K. Sarma, S.S. Gupta, K.G. Bhattacharyya, "Adsorption of Crystal violet on raw and acid-treated montmorillonite, K10, in aqueous suspension.” J. Environ. Manag, vol. 171, pp. 1-10, 2016.

[37] M. I. Carretero, M. Pozo, "Clay and non-clay minerals in the pharmaceutical industry. Part I. Excipients and medical applications," Applied Clay Science, vol. 46, pp. 73-80, 2009.

[38] D.M.E. Matike, Georges-Ivo E. Ekosse, V. M. Ngole, “ Physico-chemical properties of clayey soils used traditionally for cosmetics in Eastern Cape, South Africa," International Journal of the Physical Sciences, vol. 6. no. 33, pp. 7557 7566, 9 December 2011. [Online]. Available: http://www.academicjournals.org/IJPS. [Accessed January 11, 2019].

[39] M. Danaei, M. Dehghankhold, S. Ataei, F. Hasanzadeh Davarani, R. Javanmard, A. Dokhani, S. Khorasani, M.R. Mozafari, "Impact of Particle Size and Polydispersity Index on the Clinical Applications of Lipidic Nanocarrier Systems," Pharmaceutics, vol. 10, no. 2, pp.1-17, 2018.

\section{ACKNOWLEDGMENTS}

European Regional Development Fund Postdoctoral research aid Nr.1.1.1.2/16/I/001 research application "Identification of blue clay in lakes of Latgale region and possibilities of its application, Nr.1.1.1.2/VIAA/1/16/131".
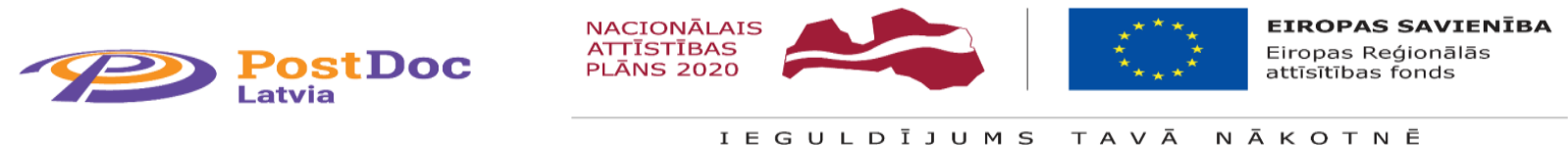